\title{
상담자에 대한 내담자의 부정적 지각 및 감정과 상담자의 역전이 행동 간의 관계
}

김현숙(金賢淑)*

\section{논문 요약}

본 연구는 상담자에 대한 내담자의 부정적 지각 및 감정과 역전이 행동 간의 관계를 알아보고자 하였다. 본 연구는 대학상담기관, 공공청소년상담기관 및 사설상담기관의 상담자-내담자 72 쌍을 대상으로 이루어졌고, 상 담자에게는 역전이 행동, 내담자에게는 상담자에 대한 부정적 지각 및 감정을 알아보기 위한 내현적 대인반응 척도를 사용하여 설문을 실시하였으며, 상관분석과 정준상관분석을 사용하였다. 본 연구의 결과를 요약하면 다 음과 같다. 첫째, 상담자에 대한 부정적 지각 및 감정과 역전이 행동은 각각 유의한 상관이 있었고, 긍정적/부정 적 역전이 행동 중에서 부정적 역전이 행동만이 각 변인과 유의한 상관이 있었다. 둘째, 상담자에 대한 내담자의 부정적 지각 변인군과 역전이 행동 변인군 간의 정준상관분석에서 각 정준변인과 상대변인군 간의 관계성을 나 타내는 정준교차부하량을 살펴본 결과, 내담자의 부정적 지각의 6개 하위변인들 모두 비슷한 정도로 상담자의 역전이 행동의 설명에 기여하고 있는 것으로 나타났다. 또한 상담자의 역전이 행동 변인군에서는 통제/훈계만이 내담자의 부정적 지각에 밀접한 연관성을 나타내는 변인으로 탐색되었다. 셋째, 내담자의 부정적 감정 변인군과 역전이 행동 변인군 간의 정준상관분석 결과, 부정적 감정의 6개 하위변인 가운데 불안/난감, 두려움/무력감이 상담자의 역전이 행동의 설명에 기여하는 것으로 나타났다. 또한 역전이 행동에서는 통제/훈계 하위변인만이 상담자에 대한 내담자의 부정적 감정의 설명에 기여하는 것으로 나타났다. 이러한 결과는 상담자에 대한 내담자 의 부정적 지각과 부정적 감정 각각은 상담자의 역전이 행동과 상호 연관되어 있음을 의미한다. 마지막으로 본 연구의 의의와 제한점 및 후속연구를 위한 제언이 논의되었다.

주요어 : 부정적 지각, 부정적 감정, 상담자-내담자, 역전이 행동

* 교신저자, 신라대학교 교육대학원 상담심리전공 조교수(강의전담교원) 


\section{I. 서론}

상담 및 심리치료에 관한 많은 연구에서 상담의 효과가 확인되고 있다. 그러나 이에 비해 상 담의 부정적 결과나 낮은 상담성과의 발생이 상대적으로 과소평가 되고(Lambert \& Ogles, 2004; Mays \& Franks, 1985), 이와 관련된 요인이나 맥락 및 상황에 관심을 두지 못했다는 의견이 제 기되고 있다(권경인, 한영주, 김창대, 유성경, 2011; Lilienfeld, 2007).

상담관계는 많은 연구에서 상담의 성공 뿐 아니라 실패의 주요 요인이라고 알려져 있다(Gelso \& Carter, 1994; Horvath \& Greenberg, 1989; Horvath \& Luborsky, 1993). 또한 상담자와 내담 자의 관계는 한 사람의 특성 또는 행동이 자신뿐만 아니라 상대방에게도 영향을 미치는 이자현 상이다(Buboltz, Deemer, \& Hoffman, 2010). 따라서 상담의 낮은 성과와 악화에 직·간접적으로 영향을 미치는 요소로서 내담자와 상담자 두 측면 모두에 실제적 주의가 요구된다. 최근의 이와 관련한 연구들에서 상담자에 대한 내담자의 부정적 상담경험(권경인 외, 2011; 손유미, 정남운, 2005)과 상담자의 역전이 행동(강소영, 한미선, 황숙양, 2008; 김현숙, 2012; 황인호, 2004)이 중요 하게 논의되고 있다.

상담자에 대한 내담자의 부정적 경험은 내담자가 상담자 요인을 어떻게 인식하고 있는 지에 대한 내담자의 상담경험에 관한 여러 연구들에서 주목을 받고 있다(강현주, 장성숙, 2006; 김현 숙, 심혜숙, 2012; 박가람, 정남운, 2008; 신재호, 정남운, 2007; 오충광, 2009). 내담자는 내담자 자신의 특성에 의해서든 상담자의 특성 및 개입 여부에 의해서든 상담자에 대해 부정적 사고와 감정을 경험할 수 있다. 내담자는 상담자와의 관계에서 부정적인 대상관계와 방어적인 태도나 사회적 관계형성의 어려움이나 저항, 적대적인 태도 등과 같은 내담자 자신의 특징적인 역기능 적 대인관계 패턴을 반복할 수도 있다(Safran \& Muran, 2000). 한편으로는, 내담자는 자신의 특 징적인 대인관계 패턴의 문제보다 현재 상담자와의 상호작용 문제를 경험할 수도 있는 것이다 (Watson \& Greenberg, 2000). 즉, 내담자는 상담자에 대한 서운함, 불신감, 화, 불쾌감 등과 같은 부정적 사고와 정서를 경험할 수 있게 된다.

이처럼 상담자에 대한 내담자의 부정적 경험은 상담의 진전과 해결을 방해하는 요인이 될 수 있으며, 자칫 치료적 난국이나 동맹결렬의 문제, 조기종결을 가져올 수 있다(김현숙, 심혜숙, 2012; 문보경, 2001; 오충광, 2009; Safran \& Muran, 1996). 더구나 내담자는 상담과정에서 부정 적 경험을 하더라도 직접 표현하기를 어려워하고 은폐성향을 보일 수 있기 때문에(Derisley \& Reynolds, 2000; Samstag, Barchelder, Muran, Safran, \& Winston, 1998; Todd, Deane, \& Bragdon, 2003) 상담자는 이를 알아차리기가 어려워 효과적인 개입에 실패할 수 있다. 이처럼 내담자의 부정적인 경험은 외현적으로 나타나는 것이든 내면화되어 잠재적으로 작용하는 것이 든 상담자에게는 다루기 힘든 영역이다. 더구나, 일반적으로 사람들은 긍정적인 정보보다는 부 
정적인 정보를 더 예민하게 지각하는 경향이 있으며, 대부분의 상담자들은 내담자의 감정에 전 염되는 경향이 있다(Jung, 1968). 따라서 상담자에 대한 내담자의 부정적 지각이나 감정에 대한 상담자의 어려움은 역전이 문제와 관련될 수 있다(김길문, 정남운, 2004).

상담자의 역전이는 내담자에 의해 유발된 상담자의 무의식적이고 신경증적인 갈등이나 감정 (Freud, 1912), 혹은 내담자에 대해 상담자가 지니는 모든 감정과 생각(Heimann, 1950), 혹은 상 담자 자신의 갈등과 욕구의 결과로 내담자에게 보이는 상담자 반응이라는 절충적 입장 (Warkins, 1985)을 포함하여 다양한 입장으로 정의된다. 역전이 행동은 상담자의 내적인 반응이 나 역전이 감정과 구별되며, 역전이를 자각하지 못하거나, 자각했다 하더라도 치료적으로 활용 되지 못하고 회기에 표면적인 행동으로 드러나는 것을 말한다(Friedman \& Gelso, 2000). 상담자 의 역전이 행동은 상담자가 내담자에게 부적절하게 반응하는 개입의 한 측면으로 상담의 실패 와 관련될 수 있으며(윤정설, 2001; Singer \& Luborsky, 1997), 특히, 내담자의 부정적 경험에 영 향을 미칠 수 있다. 이와 관련하여 Langs(1981)는 상담자의 역전이 행동은 내담자의 저항의 원인 이 될 수 있다고 주장한 바 있다. 역전이 행동 변인을 직접적으로 사용하지는 않았지만, 조성호 (1997) 또한 상담자의 부정적인 개입이 내담자의 저항을 유발할 수 있으며, 권희경(1999)도 상담 자가 판단적이고 강의하는 태도를 보일수록 내담자는 상담자와 유대감을 더 적게 느낄 수 있다 고 보고하여, 역전이 행동과 같이 부적절한 상담자 반응이 내담자의 부정적 지각이나 감정을 유 발할 수 있음을 시사하고 있다.

이상에서 살펴본 바와 같이 상담자에 대한 내담자의 부정적 지각 및 감정은 상담자의 역전이 행동에 영향을 줄 수 있는 반면, 상담자의 역전이 행동 또한 상담자에 대한 내담자의 부정적 지 각 및 감정에 영향을 미칠 수 있는 것으로 파악된다. 즉, 상담과정 중에 발생하는 상담자에 대한 내담자의 부정적 경험과 마찬가지로 상담자의 역전이 행동 또한 내담자와의 상호작용에서 발생 할 수 있는 상호작용 변인이다(Henry, Schacht, \& Strupp, 1986). 또한 Wagner, Kiesler와 Schmidt(1995)의 대인관계적 순환모델에 의하면, 상호작용하는 두 사람은 서로의 행동에 대해 상호간에 영향을 주고받는데, 한 사람의 행동은 다른 사람의 특별한 반응을 유도하거나 반응을 일으킬 수 있다. 따라서 상담자에 대한 내담자의 부정적 지각 및 감정과 상담자의 역전이 행동의 관련성은 어느 한 쪽이 일방적으로 영향을 주는 단선적인 관계로 파악되기 보다 상호 영향을 주고받는 관계로서 탐색이 요구된다.

그러나 지금까지의 연구에서 상담자에 대한 내담자의 부정적 지각 및 감정은 상대적으로 덜 주목되고 있는 상담의 내현적 과정으로서(금명자, 이장호, 1992), 상담성과 및 작업동맹 그리고 내담자의 자기대상 욕구(김미자, 2009; 김현숙, 심혜숙, 2012; 문형춘, 2007) 등 소수의 연구에 그 치고 있는 편이다. 상담자의 역전이 행동에 관한 연구 또한 역전이 행동이 대체로 상담자의 갈등 에 기반하여 표현된다는 학자들의 공통된 견해에 비추어 상담자의 특성 및 성격(김현숙, 2012; 
양경연, 2005; 윤정설, 2001), 상담자의 자기효능감(황인호, 2004), 상담자의 우울 및 성인애착(이 영순, 2012)과 같이 상담자 변인과의 관련성을 다루는 데 치중된 경향이 있다. 즉, 상담자에 대한 내담자의 부정적 지각 및 감정과 상담자의 역전이 행동 간의 관계를 탐색함에 있어 이를 동시에 고려하여 분석한 실증적 연구는 찾아보기 어렵다.

또 다른 한편으로, 상담자에 대한 내담자의 부정적 경험은 그 자체의 문제보다 이에 대한 상 담자의 개입이 치료적 활용에서 중요하다는 점에서(Bordin. 1979; Rhodes, Hill, Thompson \& Elliott, 1994), 역전이 행동을 고려해 볼 수 있다. 그러나 우선적으로 상담자에 대한 내담자의 부 정적 경험과 역전이 행동이 어떻게 상호 영향을 주고받는 지에 대한 연구가 선행될 필요가 있으 며, 이를 바탕으로 치료적 활용의 차원에서 상담자의 역전이 행동의 조절을 위한 적절한 연구의 모형이 제시될 수 있을 것이다.

따라서 이상과 같은 상담연구의 현 실정을 고려하여, 본 연구에서는 상담자에 대한 내담자의 부정적 경험과 상담자의 역전이 행동과의 상호관계 구조를 살펴보고자 한다. 이에 상담자에 대 한 내담자의 부정적 경험을 부정적 지각과 감정으로 상정하고, 각 하위변인을 군으로 묶어서 상 담자에 대한 내담자의 부정적 지각 변인군과 역전이 행동 변인군, 그리고 부정적 감정 변인군과 역전이 행동 변인군 간의 상호관계 구조를 구체적으로 확인하고자 한다. 그리하여 본 연구는 상 담의 실제에서 상담의 긍정적이고 부정적인 효과를 총체적으로 이해할 수 있는 현실감 있는 관 점과 폭넓은 시각을 제공하는 데 기여하고, 상담자 교육 및 슈퍼비전의 기초자료로 활용에 기여 할 수 있을 것으로 본다.

이상의 내용에 기초하여 설정한 구체적 연구문제들은 다음과 같다.

첫째, 상담자에 대한 내담자의 부정적 지각 변인군과 역전이 행동 변인군은 어떤 관계에 있는가? 둘째, 상담자에 대한 내담자의 부정적 감정 변인군과 역전이 행동 변인군은 어떤 관계가 있는가?

\section{ㅍ. 연구방법}

\section{1. 연구대상}

본 연구는 대학상담기관, 공공청소년상담기관, 사설상담기관 등에서 상담이 이루어지고 있는 상담자-내담자 72쌍을 대상으로 하였다. 상담자 설문은 각 상담기관의 상담자들에게 개별적인 협조를 구하여 역전이 행동 설문지를 실시하였고 상담자의 전문적인 특성을 알아보기 위한 설 문조사도 함께 이루어졌다. 내담자 설문은 각 상담자가 현재 상담을 진행하고 있는 상담사례 중 에서 내담자에게 강한 감정을 느끼거나 상담의 진행이 어렵다고 느끼는 사례를 하나 선택하게 
하여 실시하게 하였다. 본 연구에서 내담자는 5 회기 이상 진행되고 있는 사례로 제한을 하였는 데, 그 이유는 상담초기에는 전이, 역전이 발생이 부각되지 않는다(Hayes, Riker, \& Ingram, 1997)는 선행연구에 근거하였다. 본 연구의 자료수집은 직접전달 및 우편으로 총 6개월에 걸쳐 이루어졌다. 본 연구에 참여한 상담자는 남자가 6명 $(8.3 \%)$, 여자가 66 명 $(91.7 \%)$ 이었으며, 연령분 포는 25세에서 62세 범위였다 $(M=38.4, S D=8.29)$. 상담경력은 1년에서 21년 범위로, 평균 4.72년 $(S D=4.38)$ 이었고, 슈퍼비전을 받은 경험은 $86.1 \%$ 가 유경험자로, 슈퍼비전을 받은 횟수는 평균 19.52 회 $(S D=16.32)$ 이었고, $13.9 \%$ 는 슈퍼비전을 받은 경험이 없었다. 자격증 소지에 대한 복수응 답에서 1 급 자격수준(상담심리사, 전문상담사, 청소년상담사, 임상심리전문가)은 $27.2 \%$ 였고, 2 급 자격수준은 $45.7 \%$, 기타 자격증이 $27.2 \%$ 였다. 학력은 석사이하가 44 명 $(61.1 \%)$, 박사과정 이상이 28 명(38.9\%)이었다. 근무기관은 대학상담기관이 55 명 $(76.4 \%)$ 이고, 공공청소년상담기관이 13 명 $(18.1 \%)$, 사설상담기관이 4 명 $(5.5 \%)$ 이었다. 본 연구에 참여한 상담자가 진행하고 있던 사례의 내 담자 72 명은 남자가 30 명 $(41.7 \%)$, 여자가 42 명(58.3\%)이었으며, 연령은 14 세에서 47 세 범위로 평 균 26.79세 $(S D=7.17)$ 였다. 상담자가 설문에 참여할 당시 상담회기는 5 회기에서 70 회기 범위로 평균 13.71회기 $(S D=11.72)$ 였고, 학력은 대졸이하가 62 명 $(86.1 \%)$, 석사이상이 10 명 $(13.9 \%)$ 이었다.

\section{2. 측정도구}

\section{1) 역전이 행동(Inventory of Countertransference Behavior)}

역전이 행동 척도는 Friedman과 Gelso(2000)가 개발하고 김지은과 조성호(2006)가 타당화한 척도를 사용하였다. 이 척도는 총 17 문항이며 5점 리커트 척도로 응답하도록 되어있으며, 무관 심/배척, 통제/훈계, 과잉지지 3 요인으로 구성되어 있다. 무관심/배척과 통제/훈계는 부정적 역전이 행동으로, 과잉지지는 긍정적 역전이 행동으로 나눌 수 있다. 역전이 행동 전체 내적합치 도는 .72이며, 하위척도는 순서대로 $.79, .70, .77$ 이었다. 본 연구에서 전체 내적합치도는 .77 이며, 하위척도는 순서대로 $.74, .68, .64$ 이다. 또한 부정적 역전이 행동은 .77, 긍정적 역전이 행동은 .64이다.

\section{2) 내현적 대인반응(Covert Interpersonal Reaction Inventory)}

본 연구에서는 상담자에 대한 내담자의 부정적 지각과 감정을 측정하기 위해 내현적 대인반 응 척도를 사용하였다. 내현적 대인반응 척도(Covert Interpersonal Reaction Inventory)는 Kiesler(1988)와 Luborsky와 Crits-Christoph(1998)의 연구를 바탕으로 김지은과 조성호(2004)가 
개발하였다. 내현적 대인반응은 총 182 문항으로, 대인지각 66 문항, 대인감정 57 문항, 대인소망 59문항으로 구성되며, 각 요소는 긍정적 요인과 부정적 요인으로 구분된다. 본 연구에서 부정적 지각은 상담자가 자신을 부정적으로 대한다고 지각하는 것이며, 부정적 감정은 상담자와 있을 때 갖게 되는 부정적인 감정을 말한다. 김지은과 조성호의 연구에서 대인지각의 전체 내적합치 도는 .80 이고, 각 요인별 신뢰도는 .81 .95이다. 대인감정의 전체 내적합치도는 .90 이고 각 요인 별 신뢰도는 .79 .96이다. 본 연구에 사용된 부정적 지각은 대인지각의 부정적 요인으로 구분된 총 39문항으로, 하위척도는 불안정/무력, 지배, 거부, 건방/거만, 공격, 회피/경계 6요인이며, 부 정적 지각 전체 내적합치도는 .97 이며, 하위척도는 순서대로 $.88, .87, .88, .72, .90, .88$ 이다. 또한 부정적 감정은 대인감정의 부정적 요인으로 구분된 총 31 문항으로, 하위척도는 혐오/분노, 수치 /죄책감, 연민/동정, 불안/난감, 두려움/무력감, 우울/질투심 6요인이며, 부정적 감정 전체 내 적합치도는 .97 이며, 하위척도는 순서대로 $.90, .82, .89, .89, .86, .88$ 이다.

\section{3. 자료분석}

본 연구는 상담자에 대한 내담자의 부정적인 지각 변인군과 및 부정적인 감정 변인군과 상담 자의 역전이 행동 변인군 간의 상호관계의 구조를 각각 분석하기 위하여 정준상관분석 (Canonical Correlation Analysis)을 실시하였다. 정준상관분석은 각각 두 개 이상의 변인을 포함 하고 있는 두 변인군 내의 변인들간의 관계를 고려하면서 동시에 두 변인군 간의 관계를 탐색할 때 적합한 분석방법이다(이영준, 2002). 정준상관분석은 SPSS 18.0 프로그램에서 Macro를 이용 하여 실시하였다.

\section{III. 연구결과}

\section{1. 상담자에 대한 내담자의 부정적 지각 변인군과 역전이 행동 변인군의 관계}

정준상관분석을 실시하기에 앞서 <표 $1>$ 은 내담자의 부정적 지각 및 감정과 역전이 행동의 평균 및 상관관계를 보여주고 있다. 먼저, 내담자의 부정적 지각의 경우 평균이 2.01, 부정적 감 정이 1.82 , 상담자의 역전이 행동이 2.39로 본 연구대상은 실제로 상담자에 대해 부정적 지각과 부정적 감정에 있다고 보기 어려운 수준이며, 상담자의 역전이 행동의 경우 또한 보통보다 낮은 수준으로 역전이 행동이 나타나고 있다고 보기 어려운 수준으로 볼 수 있다. 다음으로 <표 1>에 나타난 바와 같이 내담자의 부정적 지각 및 감정과 역전이 행동의 평균 및 상관관계는 유의미한 
것으로 나타났다. 하위요인을 고려해 보면 내담자가 상담자에 대해 부정적으로 지각하고 부정적 인 감정을 가질수록 상담자의 무관심/배척, 통제/훈계의 경향이 높아진다는 것을 보여준다. 그 러나 역전이 행동의 과잉지지 요인은 내담자의 부정적 지각 및 감정과의 상관관계는 유의미하 지 않은 것으로 나타났다. 즉, 내담자의 부정적 지각 및 감정은 상담자의 긍정적 역전이 행동(과 잉지지)보다 부정적 역전이 행동(무관심/배척, 통제/훈계)과 더 밀접하게 관련된 것으로 볼 수 있다.

<표 1> 상담자에 대한 내담자의 부정적 지각 및 감정과 역전이 행동 간 상관관계 $(N=72)$

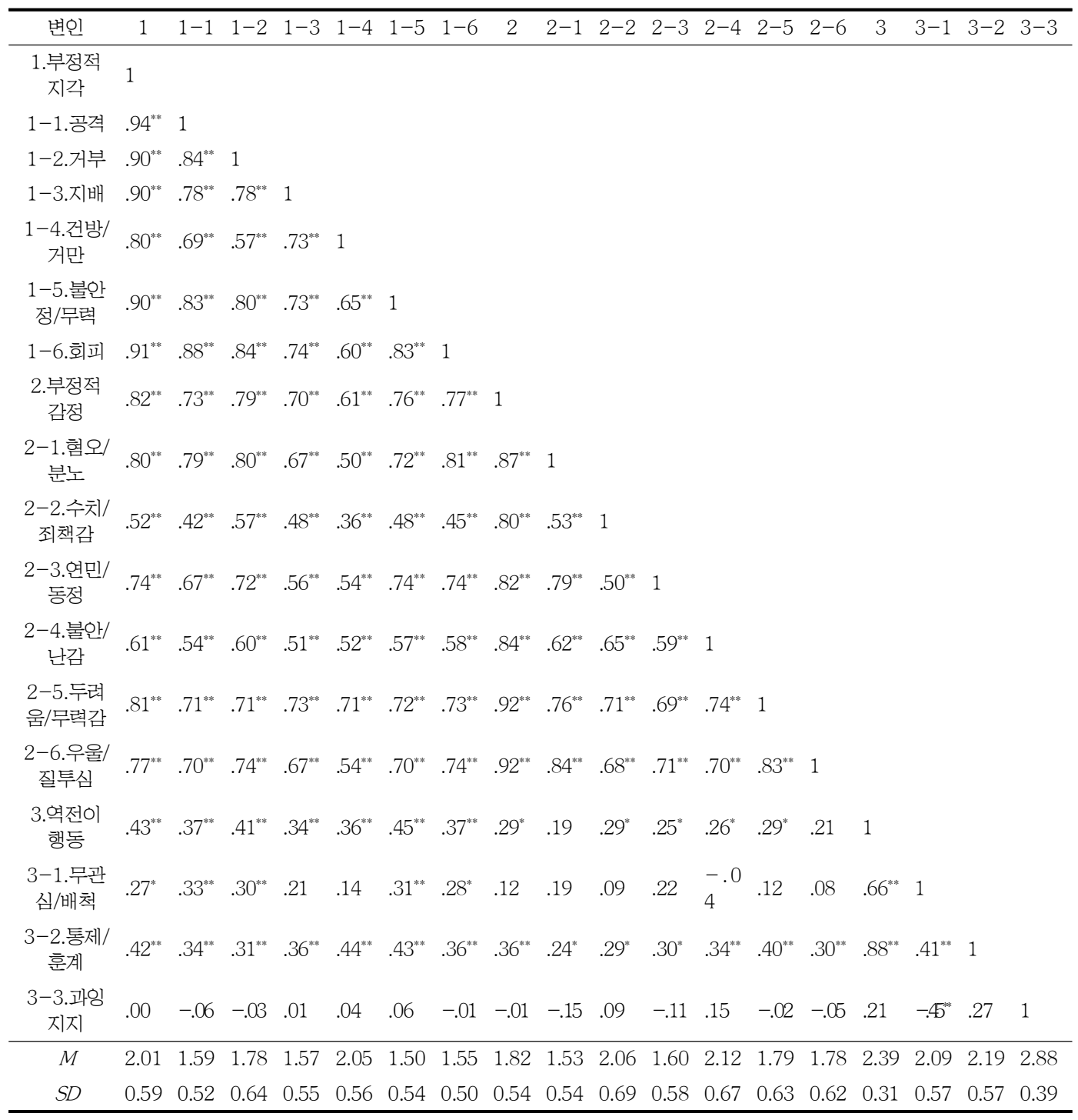


다음으로 내담자의 부정적 지각과 역전이 행동 간의 단순상관관계를 넘어서 각 하위요인들이 어떠한 구조로 서로 관계를 맺고 있는지 구체적으로 살펴보기 위하여 내담자의 부정적 지각의 하위요인을 부정적 지각 변인군으로, 역전이 행동의 하위요인을 역전이 행동 변인군으로 하여 정준상관분석을 실시하였다. <표 2>에 나타난 바와 같이 정준상관분석을 실시한 결과 3 개의 정 준상관함수가 산출되었다. 이 함수들의 유의미성을 알아보기 위해 wilk's Lambda값을 산출한 결과 제 1 정준상관함수(wilks' $\lambda=.64, p<.05)$ 만 유의한 것으로 나타났고, 제2정준상관함수, 제3정 준상관함수는 통계적으로 유의하지 않게 나타났다. 이는 제 1 정준상관함수에서 내담자의 부정적 지각 변인군과 역전이 행동 변인군이 통계적으로 유의한 관계를 가진다는 것을 의미한다. 따라 서 본 연구에서는 제1정준상관함수만을 해석하였다.

<표 2> 상담자에 대한 부정적 지각과 역전이 행동 하위요인 간의 정준상관분석

\begin{tabular}{cccc}
\hline 구분 & 제1정준상관함수 & 제2정준상관함수 & 제3정준상관함수 \\
\hline 정준상관계수 & .50 & .34 & .20 \\
wilk's Lambda값 & .64 & .85 & .96 \\
Chi-Square & $29.15^{*}$ & 10.58 & 2.58 \\
자유도 & 18 & 10 & 4 \\
\hline
\end{tabular}

$" p<.05$

<표 3>은 제 1 정준상관함수의 부정적 지각 변인군과 역전이 행동 변인군의 정준부하량과 정준 교차부하량을 산출한 결과이다. 정준부하량은 각 변인군의 정준변량과 해당 변수 간의 관계를 의미하고, 정준교차부하량은 상대 변수군의 정준변량과 해당 변수 간의 관계를 나타내므로 정준 교차부하량은 두 변인군이 상호 미치는 영향을 이해하는 데 용이하다.

먼저 정준부하량을 살펴보면 부정적 지각 변인군의 경우, 건방/거만이 제 1 정준상관함수를 형 성하는 데 가장 중요한 기여를 했으며, 다음으로 불안정/무력, 거부, 공격, 회피 순으로 나타났 다. 역전이 행동 변인군의 경우에는 통제/훈계의 정준부하량이 가장 높았고 그 다음으로 무관심 /배척이 뒤를 이었다. 부정적 지각 변인들의 정준상관함수가 부정적 지각 변인군의 분산을 설명 하는 양은 $62 \%$ 였고, 역전이 행동 변인들의 정준상관함수가 역전이 행동 변인군의 분산을 설명 하는 양은 $40 \%$ 였다.

다음으로 정준교차부하량을 살펴본 결과, 내담자의 부정적 지각의 6개 하위변인들의 부하량 이 -.35 -.43에 분포하고 있어 모든 하위변인이 비숫한 정도로 상담자의 역전이 행동의 설명에 기여하고 있는 것으로 나타났다. 즉, 상담자에 대한 내담자의 부정적 지각이 덜 나타날수록 상담 자의 역전이 행동이 덜 나타난다고 볼 수 있다. 상담자의 역전이 행동 변인군에서는 통제/훈계 
(부하량= -.99)가 내담자의 부정적 지각과 높은 상관을 나타냈고, 구조계수가 .30 이상인 것을 유의미하게 해석할 수 있다는 Tabachnick와 Fidell(1996)의 제안에 따라, 무관심/배척과 과잉지 지는 .30을 넘지 않으므로 내담자의 부정적 지각에 유의한 영향을 주지 않는다고 볼 수 있다. 이러한 결과를 종합하면, 내담자가 상담자에 대해 건방/거만, 불안정/무력, 거부, 지배, 회피, 공 격적이라고 지각하지 않을수록 상담자의 역전이 행동은 덜 나타나며, 내담자의 부정적 지각의 하위변인 가운데 두드러진 기여도를 보이는 특정 변인이 발견되지 않았고, 모든 변인이 비슷한 정도로 역전이 행동의 설명에 기여하고 있는 것으로 나타났다. 또한 역전이 행동에서는 통제/훈 계 하위변인이 내담자의 부정적 지각에 두드러진 기여도를 보이는 것으로 나타났는데, 즉, 상담 자가 통제/훈계하는 반응이 적을수록 상담자에 대한 내담자의 부정적 지각은 덜 나타난다는 것 을 보여주었다. 정준중복지수는 각각 .15와 .10으로 나타나 역전이 행동 정준상관함수가 내담자 의 부정적 지각을 설명하는 양이 $15 \%$ 이고, 역전이 행동이 내담자의 부정적 지각의 정준상관함 수에 의해 설명되는 양은 $10 \%$ 이다.

<표 3> 상담자에 대한 부정적 지각과 역전이 행동 하위요인의 정준부하량과 정준교차부하량

\begin{tabular}{|c|c|c|c|}
\hline & & \multicolumn{2}{|c|}{ 제1정준함수 } \\
\hline & & 정준부하량 & 정준교차부하량 \\
\hline \multirow{8}{*}{$\begin{array}{c}\text { 상담자에 대한 } \\
\text { 내담자의 부정적 } \\
\text { 지각 변인군 }\end{array}$} & 공격 & -.70 & -.35 \\
\hline & 거부 & -.81 & -.40 \\
\hline & 지배 & -.73 & -.37 \\
\hline & 건방/거만 & -.87 & -.43 \\
\hline & 불안정/무력 & -.86 & -.43 \\
\hline & 회피 & -.60 & -.36 \\
\hline & 분산 & \multicolumn{2}{|c|}{.62} \\
\hline & 정준중복지수 & \multicolumn{2}{|c|}{.15} \\
\hline \multirow{5}{*}{$\begin{array}{c}\text { 상담자의 역전이 } \\
\text { 행동 변인군 }\end{array}$} & 무관심/배척 & -.42 & -.21 \\
\hline & 통제/훈계 & -.99 & -.50 \\
\hline & 과잉지지 & -.16 & .08 \\
\hline & 분산 & \multicolumn{2}{|c|}{.40} \\
\hline & 정준중복지수 & \multicolumn{2}{|c|}{.10} \\
\hline
\end{tabular}

\section{2. 상담자에 대한 내담자의 부정적 감정 변인군과 역전이 행동 변인군의 관계}

<표 $4>$ 에 나타난 바와 같이 정준상관분석을 실시한 결과 3 개의 정준상관함수가 산출되었다. 이 함수들의 유의미성을 알아보기 위해 wilk's Lambda값을 산출한 결과 제1정준상관함수 
(wilks' $\lambda=.61, p<.05$ )만 유의한 것으로 나타났고, 제2정준상관함수, 제3정준상관함수는 통계적 으로 유의하지 않게 나타났다. 이는 제 1 정준상관함수에서 내담자의 부정적 감정 변인군과 역전 이 행동 변인군이 통계적으로 유의한 관계를 가진다는 것을 의미한다. 따라서 본 연구에서는 제 1정준상관함수만을 해석하였다.

<표 4> 상담자에 대한 부정적 감정과 역전이 행동 하위요인 간의 정준상관분석

\begin{tabular}{cccc}
\hline 구분 & 제1정준상관함수 & 제2정준상관함수 & 제3정준상관함수 \\
\hline 정준상관계수 & .51 & .37 & .23 \\
wilk's Lambda값 & .61 & .82 & .95 \\
Chi-Square & $32.23^{*}$ & 12.91 & 3.48 \\
자유도 & 18 & 10 & 4 \\
\hline
\end{tabular}

${ }^{*} p<.05$

<표 5>는 제 1 정준상관함수의 부정적 감정 변인군과 역전이 행동 변인군의 정준부하량과 정준 교차부하량을 산출한 결과이다. 먼저 정준부하량을 살펴보면 내담자의 부정적 감정 변인군의 경 우, 불안/난감이 제 1 정준상관함수를 형성하는 데 가장 중요한 기여를 했으며, 다음으로 두려움/ 무력감, 수치/죄책감, 우울/질투심 순으로 나타났다. 역전이 행동 변인군의 경우에는 통제/훈계 의 정준부하량이 가장 높았고 그 다음으로 과잉지지, 무관심/배척이 뒤를 이었다. 부정적 감정 변인들의 정준상관함수가 부정적 감정 변인군의 분산을 설명하는 양은 $27 \%$ 였고, 역전이 행동 변인들의 정준상관함수가 역전이 행동 변인군의 분산을 설명하는 양은 $30 \%$ 였다.

다음으로 정준교차부하량을 살펴본 결과, 내담자의 부정적 감정의 6개 하위변인들 중, 불안/ 난감(부하량=-.41)과 두려움/무력감(부하량=-.30) 두 하위변인만이 상담자의 역전이 행동의 설명 에 기여하고 있는 것으로 나타났다. 즉, 상담자에 대한 내담자의 부정적 감정 중, 불안/난감, 두 려움/무력감을 덜 느낄수록 상담자의 역전이 행동이 덜 나타난다고 볼 수 있다. 역전이 행동 변인 가운데는 통제/훈계(부하량= -.36)가 내담자의 부정적 감정과 유의한 상관을 나타냈고, 반 면, 무관심/배척과 과잉지지는 .30을 넘지 않으므로 내담자의 부정적 감정과 유의한 관계에 있 지 않다고 볼 수 있다. 이러한 결과를 종합하면, 내담자가 상담자에 대해 불안/난감, 두려움/무 력감을 덜 느낄수록 상담자의 역전이 행동은 덜 나타나며, 내담자의 부정적 감정의 6개 하위변 인 가운데 불안/난감, 두려움/무력감이 상담자의 역전이 행동의 설명에 기여하는 변인으로 발 견되었다. 또한 역전이 행동에서는 통제/훈계 하위변인이 내담자의 부정적 감정에 두드러진 기 여도를 보이는 것으로 나타났는데, 상담자가 통제/훈계하는 반응이 적을수록 상담자에 대한 내 담자의 부정적 감정은 덜 나타난다는 것을 보여준다. 정준중복지수는 각각 .07과 .08로 나타나 역전이 행동의 정준상관함수가 내담자의 부정적 감정을 설명하는 양이 $7 \%$ 이고, 역전이 행동이 
내담자의 부정적 감정의 정준상관함수에 의해 설명되는 양은 $8 \%$ 이다.

<표 5> 상담자에 대한 부정적 감정과 역전이 행동 하위요인의 정준부하량과 정준교차부하량

\begin{tabular}{|c|c|c|c|}
\hline & & \multicolumn{2}{|c|}{ 제1정준함수 } \\
\hline & & 정준부하량 & 정준교차부하량 \\
\hline \multirow{8}{*}{$\begin{array}{c}\text { 상담자에 대한 } \\
\text { 내담자의 부정적 감정 } \\
\text { 변인군 }\end{array}$} & 혐오/분노 & -.16 & -.08 \\
\hline & 수치/죄책감 & -.55 & -.28 \\
\hline & 연민/동정 & -.21 & -.11 \\
\hline & 불안/난감 & -.80 & -.41 \\
\hline & 두려움/무력감 & -.60 & -.30 \\
\hline & 우울/질투심 & -.50 & -.25 \\
\hline & 분산 & \multicolumn{2}{|c|}{.27} \\
\hline & 정준중복지수 & \multicolumn{2}{|c|}{.07} \\
\hline \multirow{5}{*}{$\begin{array}{c}\text { 상담자의 역전이 행동 } \\
\text { 변인군 }\end{array}$} & 무관심/배척 & .35 & .18 \\
\hline & 통제/훈계 & -.71 & -.36 \\
\hline & 과잉지지 & -.52 & -.27 \\
\hline & 분산 & \multicolumn{2}{|c|}{.30} \\
\hline & 정준중복지수 & \multicolumn{2}{|c|}{.08} \\
\hline
\end{tabular}

\section{IV. 논의}

상담과정에서 내담자와 상담자 간에 발생하는 현상들은 각 상호작용자의 대인관계 행동이 동 시에 상대방 행동의 원인과 결과가 되는 상호적인 인과관계로 볼 수 있다(Wagner et al., 1995). 본 연구는 이와 같은 상호작용적 관점에서 상담자와 내담자의 관계에서 상담자에 대한 내담자 의 부정적 지각 및 부정적 감정과 역전이 행동 간에 어떤 관계가 있는지를 구체적으로 확인하고 자 하였다. 정준상관분석의 결과, 상담자에 대한 내담자의 부정적 지각과 역전이 행동 간에 밀접 한 연관성이 나타났고, 상담자에 대한 내담자의 부정적 감정과 역전이 행동 간에도 밀접한 연관 성이 있는 것으로 나타났다. 본 연구에서 나타난 주요결과와 이에 대한 논의는 다음과 같다.

첫째, 상담자에 대한 내담자의 부정적 지각 및 감정과 역전이 행동과의 단순상관관계는 유의 미한 것으로 나타났다. 하위요인을 고려해 보면 내담자가 상담자에 대해 부정적으로 지각하고 부정적인 감정을 가질수록 상담자의 무관심/배척, 통제/훈계의 경향이 높아진다는 것을 보여준 다. 그러나 역전이 행동의 과잉지지 요인과 상담자에 대한 내담자의 부정적 지각 및 감정과의 상관관계는 유의미하지 않은 것으로 나타났다. 즉, 상담자에 대한 내담자의 부정적 지각 및 감정 
은 상담자의 긍정적 역전이 행동(과잉지지)보다 부정적 역전이 행동(무관심/배척, 통제/훈계)과 더 밀접하게 관련된 것으로 볼 수 있다. 이와 같은 결과는 내담자가 상담자에 대해 부정적으로 지각하거나 부정적 감정을 가질수록 상담자는 긍정적 역전이 행동보다 부정적인 역전이 행동이 높아질 가능성을 나타낸다고 볼 수 있다. 이는 상담과정에서 부정적 역전이 행동이 더 조절되기 어렵고(윤정설, 2001), 내담자의 회기 평가에서 부정적 역전이 행동이 긍정적 역전이 행동보다 상대적으로 더 큰 영향력을 가지고 있어(강석영, 2007), 상담자의 부정적 역전이 행동에 더 초점 을 둘 필요가 있다는 김현숙(2012)의 주장과도 맥락을 같이 한다. 그러나 상담자의 긍정적 역전 이 행동은 상담 초기에 내담자에게 지지와 공감으로 지각되어 작업동맹 형성에 긍정적 영향을 줄 수도 있다(황인호, 2004)는 점에서, 상담자의 긍정적 역전이 행동과 내담자의 경험에 대한 부 정적인 관련성은 상담과정의 다른 변인들을 고려하여 재검토할 필요가 있을 것으로 본다.

둘째, 상담자에 대한 내담자의 부정적 지각 변인군(불안정/무력, 지배, 거부, 건방/거만, 공격, 회피/경계)과 역전이 행동 변인군(무관심, 통제/훈계, 과잉지지) 간의 정준상관분석의 결과, 3 개 의 정준상관함수가 도출되었으나, 실제적인 의미가 거의 없는 2 개의 함수는 제외하고 제 1 정준상 관함수만을 해석하였다. 각 정준변인과 상대변인군 간의 관계성을 나타내는 정준교차부하량을 살펴본 결과, 내담자의 부정적 지각의 6개 하위변인들 모두 비슷한 정도(부하량 -.35 -.43)로 상 담자의 역전이 행동의 설명에 기여하고 있는 것으로 나타났다. 즉, 상담자에 대한 내담자의 부정 적 지각이 덜 나타날수록 상담자의 역전이 행동이 덜 나타난다고 볼 수 있다. 상담자의 역전이 행동 변인군에서는 통제/훈계만이 내담자의 부정적 지각에 밀접한 연관성을 나타내는 변인으로 탐색되었다. 즉, 상담자가 통제/훈계 행동을 덜 할수록 내담자는 상담자에 대한 부정적 지각은 낮아진다는 사실을 말해주고 있다.

셋째, 상담자에 대한 내담자의 부정적 감정 변인군(혐오/분노, 수치/죄책감, 연민/동정, 불안 /난감, 두려움/무력감, 우울/질투심)과 역전이 행동 변인군(무관심, 통제/훈계, 과잉지지) 간의 정준상관분석의 결과, 3 개의 정준상관함수가 도출되었으나, 실제적인 의미가 거의 없는 2 개의 함수는 제외하고 제 1 정준상관함수만을 해석하였다. 정준교차부하량을 살펴본 결과, 내담자의 부정적 감정의 6 개 하위변인 가운데 불안/난감, 두려움/무력감이 상담자의 역전이 행동의 설명 에 기여하는 변인으로 나타났다. 또한 역전이 행동에서는 통제/훈계 하위변인이 내담자의 부정 적 감정에 두드러진 기여도를 보이는 것으로 나타났다.

이상의 결과는 상담자에 대한 내담자의 부정적 지각과 부정적 감정 각각은 상담자의 역전이 행동과 상호 밀접하게 연관되어 있음을 말해준다. 이는 상호작용하는 상대방에 의해 인지, 정서, 행동경향성의 경험이 일어날 수 있다는 Kiesler(2001)의 주장과 대인관계적 순환모델(Wagner et al., 1995)과 연관지어 이해할 수 있다. 또한 상담현상들은 상담자와 내담자간의 상호작용적 관점 에서 이해하고 설명하려는 상담과정 연구들(Buboltz et al., 2010; Hill \& Williams, 2000)과 본 
연구결과는 상통한다. 이에 대해 상담자에 대한 내담자의 부정적 경험과 상담자의 역전이 행동 의 촉발 요인으로 내담자 혹은 상담자 어느 쪽이 먼저라고 말할 수는 없지만 두가지 방향 모두 를 고려해 볼 수 있다. 먼저, 내담자 측면이 상담자의 역전이 행동의 유발자극이 될 수 있다. 이 와 관련하여 김길문과 정남운(2004)이 상담자에 대한 내담자의 부정적 지각이나 감정에 대해 상 담자가 역전이 문제와 관련될 수 있다고 언급한 것처럼, 상담자는 역전이 행동의 조절에 실패할 수 있음을 보여준다. 특히 본 연구결과는 상담자가 내담자를 통제하고 훈계하는 부정적 역전이 행동이 나타날 가능성을 보여주고 있다. 특히 방어적인 성격(신희천, 1995)과 대인관계의 어려움 (Constantino \& Smith-Hansen, 2008)의 특성을 가진 내담자는 낮은 상담성과와 관련된 것으로 나타나 상담자에 대해 부정적 지각이나 감정을 더 쉽게 가질 수 있다. 이에 대해 상담자는 부정 적 상황에서 부정적 지각 및 감정을 나타내며(김지은, 2011), 상담자가 내담자에 대해 부정적 지 각이나 감정을 많이 가질수록 부정적 역전이 행동이 증가하고 긍정적 역전이 행동이 감소한다 (김지은, 조성호, 2006)고 한 바처럼, 내담자가 초래할 수 있는 부정적 상황은 상담자의 역전이 행동의 조절에 시사하는 바가 크다고 하겠다. 즉, 김창대, 한영주, 손난희 그리고 권경인(2009)의 연구에서는 상담자가 내담자 자신들의 부정적 감정, 심지어 상담자에 대한 부정적 감정까지 받 아주는 큰 용량을 가진 것을 효과적이라고 보고하여 효과적인 상담자 요인으로 상담자의 역전 이 행동의 조절이 강조됨을 재확인 할 수 있다. 다음으로 상담자 측면이 상담자에 대한 내담자의 부정적 지각 및 감정의 유발자극이 될 수 있다. 상담자의 역전이는 상담자의 성격에 그 뿌리를 두고 있고(최명식, 2003), 개인의 미해결된 무의식적 갈등과 욕구(Hayes \& Gelso, 2001)라는 데 서 알 수 있는 것처럼, 역전이에 대한 학자들의 공통된 견해는 상담자의 갈등에서 비롯된다는 점이며, 역전이 행동 또한 그 뿌리가 상담자의 갈등으로 볼 수 있다. 이다. 유능한 상담자라 할지 라도 상담 중에 부정적인 감정을 경험할 수 있으며(Peabody \& Gelso, 1982), 상담자 역시 정도 의 차이는 있지만, 내담자를 자기의 욕구충족의 수단으로 삼고자 하는 경향을 지닌 존재이다(정 방자, 1994). 이와 관련하여 김지은(2011)은 상담자 자신의 문제가 상담과정에 부정적 영향을 미 쳤던 경험과 같은 부정적 역전이 상황에서 상담자는 내담자에 대해 부정적 반응을 나타낸 것으 로 보고하였다. 본 연구결과에 따르면, 상담자가 통제하고 훈계하는 방식으로 내담자를 대할 때, 내담자는 상담자에 대해 부정적 지각을 더 가질 수 있고, 불안/난감, 두려움/무력감과 같은 부 정적 감정을 나타나게 될 수 있다는 것이다. 특히, 상담자가 양육과정의 영향으로 자신에게 적대 적인 경우에는 부정적인 대인관계 과정에 대한 상담자 교육을 받은 후에도 내담자에게 적대적 인 경향이 있으며(Henry, Strupp, Butler, Schacht, \& Binder, 1993), 어린 시절 부모님에 대한 부정적인 인식을 가지고 있는 경우, 상담과정에서 부정적인 대인관계 과정을 경험할 수 있다 (Hilliard, Henry, \& Strupp, 2000)는 점을 고려할 때, 이러한 상담자 측면이 상담자에 대한 내담 자의 부정적 경험에 미칠 수 있는 영향은 본 연구결과와 연관지어 볼 때 시사하는 바가 크다. 
본 연구의 의의는 첫째, 상담의 요구가 급증하고 있는 한국 상담의 현실정에서 상담의 효과 뿐만 아니라 상담성과에 부정적 영향을 미치는 대표적 요인으로 상담자에 대한 내담자의 부정 적 경험과 상담자의 역전이 행동을 함께 고려하여 그 관계의 탐색을 시도했다는 점이다. 본 연구 에서 상담자와 관련된 내담자의 부정적 경험과 역전이 행동 간의 상호 관계를 구체적으로 제시 함으로써, 역전이가 상담자 자신에 의해서도 발생하지만, 역전이 내담자에 의해 유발될 수도 있 는 양인적 현상(bipersonal phenomenon)으로 이해할 수 있음을 시사한다고 볼 수 있다.

둘째, 본 연구에서 새롭게 발견한 점은 상담자와 내담자와의 부정적인 대인관계 상황에서 상 담자에게 나타나는 두드러진 역전이 행동이 내담자를 통제하거나 훈계하는 방식이라는 점이다. 상담자에 대한 내담자의 부정적 지각과 감정과 상담자의 역전이 행동 간의 단순상관관계에서는 상담자의 부정적 역전이 행동으로 무관심/배척, 통제/훈계 모두 유의한 관계에 있는 것으로 나 타났지만, 각 변인군과의 관계를 전체적으로 파악하는 데 목적을 둔 정준상관분석에서는 상담자 의 부정적 역전이 행동 중 통제/훈계만 밀접한 연관성이 나타났다는 점이다. 이러한 점은 한국 내담자의 특성과 상담자의 특성 두 가지 측면과 관련지어 볼 수 있을 것이다. 즉, 상담자 측면에 서는 상담관계가 인간적으로는 대등한 관계이지만, 내담자를 도와주어야 한다는 관점에서 보면 대등하지 않는 관계일 수 있으며, 과제지향적인 관계 측면이 있을 수 있다. 따라서 누구에 의해 촉발이 되든 부정적 상황에서 상담자는 내담자를 통제하거나 훈계 하는 수직적 관계의 입장을 취하기 쉬울 수 있다고 볼 수 있다. 또한 내담자 측면에서도 유교문화와 관료적인 체제를 주로 접해온 한국의 내담자들은 권위적인 대상에 익숙해 있을 수 있으나, 반면 그에 대한 부적절함과 이전과는 다른 존경할 수 있는 인간적인 권위자 상을 만나고자 하는 욕구가 있을 수 있다. 이에 상담자가 통제하거나 훈계하려는 태도를 보일 때, 기존의 익숙한 권위자상이 투사되거나 경험될 수 있으므로 상담자에 대해 부정적 지각이나 부정적 감정을 더 가질 수 있다고도 볼 수 있다. 이와 같은 점은 추후 내담자의 경험과 상담자의 역전이 문제와 관련하여 한국 내담자의 특성 및 상담자의 권위적 특성에 대한 연구의 촉진에 도움이 될 수 있을 것이다.

셋째, 본 연구는 상담자와 내담자 각 상호작용자의 대인관계 행동이 동시에 상대방 행동의 원인과 결과가 되는 상호적인 관계를 파악하고자 하였다. 그러나 특히 최근에는 여러 연구의 메 타분석을 통해 어떤 특정한 치료법보다 어떤 상담자가 상담을 하느냐가 핵심적인 요소라고 밝 혀지고 있어(Wampold, 2006), 어느 때보다 치료적 요인으로서의 상담자 역할의 비중이 크게 인 식되고 있다. 이러한 측면에서 본 연구는 내담자의 상황이나 특성에 따라 상담자의 개입이나 역 할에서 융통성이 강조됨을 시사한다. 이와 관련하여 본 연구가 갖는 의의는 상담자에 대한 내담 자의 부정적 경험을 통해 상담자가 기여한 부분을 확인할 수 있었다는 점이며, 이는 효과적인 상담에 필요한 정보를 확보할 수 있게 한다는 것이다(문보경, 2001; Safran, 1993). 즉, 상담자의 적절한 역전이 행동의 조절은 내담자로 하여금 부정적 지각 및 감정 표현을 통해 상담과정이나 
상담자에 대한 부정적 감정의 해소, 왜곡된 지각의 수정, 새로운 정보의 획득 등과 같은 치료적 경험을 하게 되고, 이는 내담자가 상담자를 더욱 신뢰하게 만드는 계기가 될 수 있게 한다는 점 이다(오충광, 2009). 이에 본 연구는 상담자 교육에서 역전이 해결의 중요성을 더욱 강조하고 자 기분석 및 지도감독, 교육분석 뿐 아니라, 역전이 연구를 더 활성화시키고 촉진시키는 역할을 할 수 있다고 본다.

본 연구의 제한점 및 후속연구를 위한 제언은 다음과 같다.

첫째, 본 연구에 참여한 내담자들이 보고한 상담자에 대한 내담자의 부정적 지각 및 감정의 평균(M=1.53 2.06)을 볼 때, 실제로 상담자를 부정적으로 경험하고 있기보다 어느 정도 긍정적 인 관계로 지각하고 있음을 고려하여 해석할 필요가 있다. 따라서 앞으로의 연구는 작업동맹을 어렵게 할 정도로 상담자에 대해 부정적인 지각과 감정을 경험하는 내담자들에 대해 상담자의 역전이 행동이 어떻게 나타나는 지에 대해 알아볼 필요가 있을 것이다. 둘째, 본 연구에서 상담 자에 대한 내담자의 부정적 지각과 감정, 상담자의 역전이 행동의 측정은 5 회기에서 70 회기 범 위로 평균 13.7회기 정도에 이루어졌다고 볼 수 있다. Kivlighan과 Shaughnessey(2000)은 작업 동맹이 상담회기가 진행되면서 U형(고-저-고) 패턴을 가지게 되며, 비록 성공적인 상담 성과를 보인 사례라 할지라도 상담의 전 과정에서 걸쳐 작업동맹의 위기가 적어도 한 번 이상은 발생하 게 된다고 하였다(Safran, Crocker, McMain, \& Murray, 1990). 따라서 상담자와 내담자의 부정 적 상황을 전제로 한 본 연구에서는 측정의 시기의 범위가 넓어 사례에 따라서는 작업동맹의 위기가 시사하는 상담자와 내담자 간의 부정적인 상황이 해결되었을 가능성도 있어, 결국 모든 사례가 동일하게 부정적인 상황에 놓여 있다고 보기가 어려울 수 있다. 본 연구가 실제 상담에 참여하는 상담자와 내담자를 대상으로 하며, 특히 내담자의 경우, 연구의 참여에 다소 거부감이 나 저항이 따를 수 있는 현 실정에서 74 사례에 대하여 측정회기를 비슷하게 제한하기 어려웠다 는 한계를 고려하여 본 연구결과의 해석에 신중을 기할 필요가 있다. 따라서 상담회기에 따른 세부적 탐색이 앞으로의 연구에서 이루어질 필요가 있다. 셋째, 본 연구는 양적인 연구방법으로 내담자-상담자 간의 상호관계를 파악하고 있어, 직접적인 상호작용과정을 나타내지는 못하였다. 앞으로의 연구에서는 실제 상담사례가 진행되는 과정에서의 상호작용 분석과 양적방법을 병행 하여 내담자-상담자 간의 부정적 경험 및 갈등 관계를 탐색해 볼 필요가 있을 것으로 본다. 넷째, 추후 연구에서는 내담자에게 일어나는 부정적인 경험은 상담자에 대한 감정이나 지각 뿐 아니 라, 자신에 대한 부정적인 관계양식, 예컨대, 적대적이거나 방어적이거나 분노를 잘 경험하는 등 의 상담과정을 어렵게 만드는 내담자에 대한 연구들이 상담자의 경험과 관련하여 이루어질 필 요가 있다. 즉, 내담자의 부정적 경험과 상담자의 역전이 행동 및 기타 부정적 경험 간에 존재하 는 변인들이 무엇인지 탐색적으로 살펴보고, 그것을 바탕으로 조건 혹은 경로를 밝혀낼 필요가 있을 것이다. 마지막으로, 상담현장을 다양하게 고려한 연구가 시도될 필요가 있다. 청소년 상 
담, 대학상담, 일반성인 상담, 학교상담 등 각 상담현장만의 고유한 어려움을 가진 내담자 특성 이 있을 것이며 그에 맞는 상담자 역할이 요구될 것이다. 따라서 추후 연구에서는 각 상담현장의 내담자 특성과 경험과 관련한 상담자의 역전이 경험 연구가 질적/양적 연구방법이 병행되어 시 도될 필요가 있을 것이다. 이에 상담현실이 적극적으로 반영된 다양한 장면의 상담자-내담자에 관한 연구 자료들을 바탕으로 상담자의 전문성 발달에 기여할 수 있는 상담교육 과정이 개발되 고 실천 교육 프로그램의 적용이 이루어져야 할 것이다. 


\section{참고문헌}

강석영(2007). 상담자 자기효능감과 상담성과의 관계에서 상담자 역전이 행동 및 내담자 협력관 계의 매개효과. 박사학위논문, 단국대학교.

강소영, 한미선, 황숙양(2008). 상담자의 자기애적 특성이 상담과정에 미치는 영향: 역전이 관리

와 역전이 행동과의 관계를 중심으로. 한국심리학회지 : 상담 및 심리치료, 20(4),

947-962.

강현주, 장성숙(2006). 상담에서 도움된 경험에 관한 질적 분석. 경희 대학교 학생생활연구, 11 ,

947-962.

권경인, 한영주, 김창대, 유성경(2011). 상담성과가 낮은 내담자들의 상담경험에 대한 질적 분석, 상담학연구, 12(6), 1977-2005.

권희경(1999). 상담자 태도 및 저항에 대한 개입이 저항 감소와 상담 지속에 미치는 영향. 박사학 위논문, 고려대학교.

권희경, 안창일(2001). 성공 및 실패사례의 내담자 저항과 상담자 태도의 상호작용. 한국심리학 회지: 임상, 20(1), 19-36.

금명자, 이장호(1992). 상담참여자(상담자와 내담자)의 내현적 과정에 관한 개관 연구: 상담과정 모델의 발달을 위한 모색. 한국심리학회지: 상담 및 심리치료, 4(1), 1-18.

김길문, 정남운(2004). 초보 상담자가 상담 회기 내에 경험한 어려움과 대처 과정: 질적 분석. 한 국심리학회지: 상담 및 심리치료, 16(1), 1-20.

김지은(2011). 대인갈등 상황과 부정적 역전이 상황에서의 내현적 대인반응 비교. 상담학연구, 12(3), 811-833.

김미자(2009). 내담자의 자기대상 욕구와 내담자가 지각한 상담관계. 박사학위논문, 가톨릭대학 교.

김지은, 조성호(2004). 내현적 대인반응 척도의 개발 및 타당화. 한국심리학회지: 상담 및 심리 치료, 16(3), 407-434.

(2006). 역전이 행동 척도의 타당화 연구. 한국심리학회지: 상담 및 심리치료, 18(1), 117-136.

김창대, 한영주, 손난희, 권경인(2009). 상담전공 내담자가 지각한 효과적인 상담자 요인, 상담학 연구, 10(1), 83-107.

김현숙(2012). 상담자의 내현적 자기애와 작업동맹과의 관계에서 역전이 행동의 매개효과. 상담 학연구, 24(3), 485-504. 
김현숙, 심혜숙(2012). 내담자의 내현적 자기애와 부정적 전이 및 작업동맹 간의 관계. 한국심리 학회지: 상담 및 심리치료, 13(2), 33-49.

문보경(2001). 상담에 대한 내담자의 불만경험: 질적 분석. 한국심리학회지: 상담 및 심리치료, 13(2), 33-49.

문형춘(2007). 내담자 성인애착 특성에 따른 내담자 및 상담자의 내현적 대인반응과 회기성과.

박사학위논문, 가톨릭대학교.

박가람, 정남운(2008). 성폭력 상담에서 내담자들이 지각한 도움경험: 질적 분석. 한국심리학회

지: 상담 및 심리치료, 20(1), 161-182.

손유미, 정남운(2005). 초심상담자와 내담자의 조기종결 경험에 관한 질적 분석. 한국심리학회

지: 상담 및 심리치료, 17(3), 523-545.

신재호, 정남운(2007). 초보상담자의 상담성과에 관한 질적분석: 도움된 경험을 중심으로. 한국

심리학회지: 상담 및 심리치료, 19(4), 889-911.

신희천(1995). 내담자의 특성에 따른 상담상호작용 패턴과 작업동맹과의 관계. 석사학위논문, 서 울대학교.

양경연(2005). 상담자 발달수준과 자아분화 및 역전이 행동과의 관계. 석사학위논문, 가톨릭대학 교.

오충광(2009). 초기 작업동맹과 상담 불만족에 대한 개입이 후기 작업동맹에 미치는 영향. 상담 학연구, 10(3), 1471-1486.

윤정설(2001). 상담자의 성격특성 및 경력이 역전이 행동에 미치는 영향. 석사학위논문, 연세대 학교.

이영순(2012). 상담자의 우울경험과 성인애착 및 역전이 행동의 관계. 상담학연구, 13(3), 1501-1517.

이영준(2000). 정준상관분석의 이해. 서울: 석정.

정방자(1994). 심리치료에서 치료자의 자아의 확장이 내담자 치료에 미치는 영향. 효대논문집, 48, 167-185.

조성호(1997). 내담자 저항과 내담자 반발성, 상담자 개입 특성 및 작업동맹과의 관계. 박사학위 논문, 서울대학교.

최명식(2003). 역전이와 상담자의 자기 문제. 동서정신과학, 6(2), 197-214.

황인호(2004). 상담자의 자기효능감과 역전이행동 및 상담협력관계가 상담만족도에 미치는 영 향. 박사학위논문, 건국대학교.

Bordin, E. S. (1979). The generalizability of the psychoanalytic concept of the working alliance.

Psychotherapy: Theory, Research, and Practice, 16, 252-260.

Buboltz Jr., W., Deemer, E., \& Hoffman, R. (2010). Content analysis of the Journal of Counseling 
Psychology: Buboltz, Miller, and Williams (1999) 11years later. Journal of Counseling Psychology, 573), 368-375.

Constantino, M. J., \& Smith-Hansen, L. (2008). Patient interpersonal factors and the therapeutic alliance in two treatments for bulimia nervosa. Psychotherapy Research, 18, 683-698.

Derisley, J., \& Reynolds, S. (2000). The transtheoretical stages of change as a predictor of premature termination, attendance and alliance in psychotherapy. British Journal of Clinical psychology, 39, 371-382.

Freidman, S., \& Gelso, C. J. (2000). The development of the inventory of countertransference behavior. Journal of Clinical Psychology, 56, 1221-1235.

Freud, S. (1912). The dynamics of transference, In J., Strachey (ed.), The Standard edition of the complete psychological work of Sigmund Freudvol. 12), London: Hogarth.

Gelso, C. J., \& Carter, J. A. (1994). Components of the psychotherapy relationship: Their interaction and unfolding during treatment. Journal of Counseling Psychology, 41, 296-306.

Hayes, J. A., \& Gelso, C. J. (2001). Clinical implications of on countertransference: Science informing practice. Journal of Clinical Psychology, 578), 1041-1051.

Hayes, J. A., Riker, J. R., \& Ingram, K. M. (1997). Countertransference behavior and management in brief counseling: A field study. Psychotherapy Research, 72), 145-153.

Heimann, P. (1950). On countertransference. International Journal of Psychoanalysis, 31, 81-84. Henry, W. P., Schacht, T. E., \& Strupp, H. H. (1986). Structural analysis of social behavior: Application to a study of interpersonal process in difference psychotherapeutic outcome, Journal of Consulting and Clinical Psychology, 54, 27-31.

Henry, W. P., Strupp, H. H., Butler, S. F., Schacht, T. E., \& Binder, J. L. (1993). The effects of training in time-limited dynamic psychotherapy: Changes in therapist behavior. Journal of Consulting and Clinical Psychology, 61, 434-440.

Hill, C. E., \& Williams, E. N. (2000). The process of individual therapy. In S. D. Brown \& R. W. Lent (Eds.), Handbook of counseling psychology(3rd ed., pp.670-710), New York: Wiley.

Hilliard, R. B., Henry, W. P., \& Strupp, H. H. (2000). An interpersonal model of psychotherapy: Linking patient and therapist developmental history, therapeutic process, and types of outcome. Journal of Consulting and Psychology, 68, 125-133.

Horvath, A. O., \& Greenberg, L. S. (1989). Development and validation of the Working 
Alliance Inventory. Journal of Counseling Psychology, 36, 223-232.

Horvath, A. O., \& Luborsky, K. (1993). The role of the therapeutic alliance in psychotherapy. Journal of Consulting and Clinical Psychology, 61(4), 561-573.

Jung, C. G. (1968). Lecture five: Analytical counseling psychology: Its theory and practice New York: Random House.

Kiesler, D. J. (1988). Therapeutic metacommunication: Therapist impact disclosure as feedback in psychotherapy. Palo Alto, CA: Consulting Psychologists Press.

(2001). Therapist countertransference: In search of common themes and empirical referents. Journal of Clinical Psychology, 578), 1053-1063.

Kivlighan, D. M., \& Shaughnessey, P. (2000). Pattern of working alliance development: A typology of client's working alliance ratings. Journal of Counseling Psychology, 47, 362-371.

Lambert, M. J., \& Ogles, B. M. (2004). The efficacy and effectiveness of psychotherapy. In M. J. Lambert (Ed.), Bergin and Garfield's handbook of psychotherapy and behavior change (5th ed., pp. 139-193). New York: Wiley.

Langs, R. (1981). Resistances and interventions. New York : Jason Aronson.

Lilienfeld, S. O. (2007). Psychological treatments that cause harm. Perspectives on Psychological Science, 2, 53-70.

Luborsky, L., \& Crits-Christoph, P. (1998). Understanding transference: The core conflictual relationship theme method Washington, DC: American Psychological Association.

Mays, D. T., \& Franks, C. M. (1985). Negative outcome in psychotherapy and what to do about it. New York: Springer.

Peabody, S. A., \& Gelso, C. J. (1982). Countertransference and empathy: The complex relationship between two divergent concepts in counseling. Journal of Counseling Psychology, 29(3), 240-245.

Rhodes, R. H., Hill, C. E., Thompson, B. J., \& Elliott, R. (1994). Client retrospective recall of resolved and unresolved misunderstanding events. Journal of Counseling Psychology, 41, 473-483.

Safran, J. D. (1993). Breaches in the therapeutic relatedness. Psychotherapy, 30, 11-24.

Safran, J. D., Crocker, P., McMain, S., \& Murray, P. (1990). The therapeutic alliance rupture as a therapy event for empirical investigation. Psychotherapy, 272), 154-165.

Safran, J. D., \& Muran, J. C. (1996). The resolution of ruptures in the therapeutic alliance. Journal of Consulting and Clinical Psychology, 64, 447-458. 
(2000). Resolving therapeutic alliance ruptures: Diversity and integration. Journal of Clinical Psychology, 56(2), 233-243.

Samstag, L. W., Batchelder, S. T., Muran, J. C., Safran, J. D., \& Winston, A. (1998). Early identification of treatment failures in short-term psychotherapy: An assessment of therapeutic alliance and interpersonal behavior. Journal of Psychotherapy Practice \& Research, 7, 126-143.

Singer, B. A., \& Luborsky, L. (1997). Countertransference: The status of clinical versus quantitative research. In A. S. Gurman \& A. M. Razdin (Eds.), Effective psychotherapy: Handbook of research (pp. 433-451). New York: Pergamon Press.

Tabachnick, B. G., \& Fidell, L. S. (1996). Using multivariate statistics (3rd ed.). New York: HarperCollins.

Todd, D. M., Deane, F. P., \& Bragdon, R. A. (2003). Client and therapist reasons for termination: A conceptualization and preliminary validation. Journal of Clinical Psychology, 59, 133-147.

Wagner, C. C., Kiesler, D. J., \& Schmidt, J. A. (1995). Assessing the interpersonal transaction cycle: Convergence of action and reaction interpersonal circumplex measures. Journal of Personality and Social Psychology, 69(5), 938-949.

Watkins, C. E. (1985). Countertransference: Its impact on the counseling situation. Journal of Counseling and Development, 63, 356-359.

Wampold, B. E. (2006). What should be validated? The psychotherapist. In J. C. Norcross, L. E. Beutler, \& R. F. Levant (Eds.), Evidence-based practices in mental health: Debate and dialogue on the fundamental questions (pp. 200-208). Washington, DC: American Psychological Association.

Watson, J. C. \& Greenberg, L. S. (2000). Alliance Ruptures and Repairs in Experiential Therapy. Journal of Clinical Psychology, 56(2), 175-186.

* 김현숙: 부산대학교 화학과를 졸업하고, 동대학교 대학원 상담심리 및 교육심리 전공 교육학 석·박사학위를 취득하였다. 현재 신라대학교 교육대학원 상담심리전공 조교수(강의전담)로 재직 중이다. 주요논문 및 저서로는 ‘내담자의 내현적 자기애와 부정적 전이 및 작업동맹과의 관계', '상담자의 내현적 자기애가 작업동맹에 미치는 영향에서 역전이행동의 매개효과, '해결중심단기상담교육 프로그램 효과분석', '중학생의 절도행동 극복경험, '대학생의 내현적 자기애와 대학생활적 응과의 관계에서 의사소통능력의 매개효과' 등이 있다.

*E-mail:khs@silla.ac.kr 


\title{
A Relationship between Negative Perceptions and Feelings of Client on the Counselor and Countertransference Behavior of Counselor
}

\author{
Kim, Hyun-sook
}

The purpose of this study was to investigate relationship between negative perceptions/feelings of client on counselor and countertransference behavior. The subjects were 72 counselors-clients pairs who were counseling at university counseling centers, private counseling center, and youth counseling centers. They were assessed by The Countertransference Behavior Inventory, and Covert Interpersonal Reaction Inventory. SPSS 18.0 was used for implementing a canonicalcorrelation Analysis. The results showed as follows: First, negative perceptions/feelings of client on counselor and countertransference behavior showed a significant negative correlations. Second, negative perceptions of client on counselor had highly correlation with control among countertransference behavior. Third, negative feelings of client on counselor had highly correlation with control among countertransference behavior. Finally, suggestions for the limitations of this study and ideas for further research are discussed and proposed.

Key words: negative perception, negative feeling, client-counselor, countertransference behavior

* Corresponding author, Professor, Silla University 